\title{
Investigation of an Induction Wound Rotor Motor to Work as a Synchronous Generator
}

\author{
Ayman Y. Al-Rawashdeh \\ Department of Electrical Engineering, \\ Faculty of Engineering Technology, \\ Al-Balqa Applied University, \\ Amman, Jordan \\ dr.ayman.rawashdeh@bau.edu.jo
}

\begin{abstract}
This paper aims at investigating the use of an induction wound rotor motor to generate voltage instead of the old diesel engines that are still used in many factories, like old cement factories, in Jordan. In this investigation, a simulation model of induction wound rotor motor was implemented using Matlab/Simulink. The excitation DC current was connected to a two-phase rotor circuit, and the voltage-current performance characteristics were investigated and evaluated under different load types. The simulation results confirmed the possibility of using the induction wound rotor motor as a synchronous generator.
\end{abstract}

Keywords-slip ring; induction motor; synchronous generator; model; gear box; coupling; excitation; load variation

\section{INTRODUCTION}

One of the main problems of electrical supply in industry and agriculture is the interruption of the main power supply source and the need to an emergency power supply source. In most cases, the emergency power supply sources are diesel engines, e.g. the Shinko diesel engine (1982) used in Jordan cement factories (Figure 1, Table I). Diesel generators are known to cause problems especially for old engine models including their regular need to operate for at least one hour per week and the high maintenance and operative coasts. Moreover, the hardware is not available and long order and delivery times are needed.

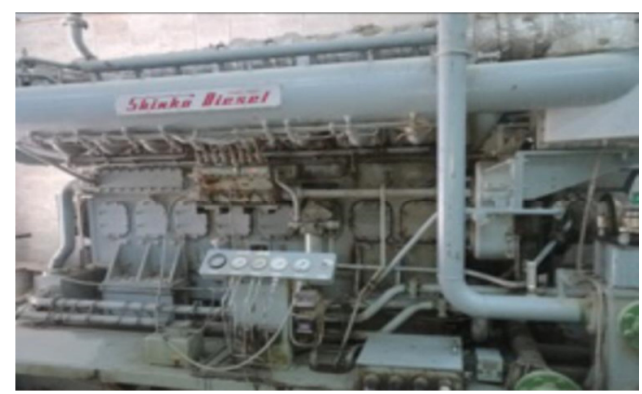

Fig. 1. A Shinko diesel engine.

Induction motors are classified by their rotor construction [1]. Of the different types, the current study investigates the use of wound rotor motor. From the known speed torque characteristic of the induction motor, the motor can act either as a motor or a generator [2]. When the speed of the induction motor is less than the synchronous speed and its slip is positive, the induction motor operates as a motor. When its speed is more than the synchronous speed and its slip is negative, the machine works as a generator. In the current investigation, a new method that allows an induction motor to operate as a generator is suggested. A wound rotor induction motor can operate as a synchronous generator based on its construction which is similar to a synchronous generator with non-salient poles. In wound rotor induction motors, the DC excitation current can be supplied to a rotor circuit through slip rings and carbon brushes. This gives the possibility of converting an asynchronous machine into a synchronous generator operation mode which can be used as an emergency power supply, which allows the utilization of power sources more effectively and efficiently.

TABLE I. SHINKO DIESEL ENGINE PARAMETERS

\begin{tabular}{|c|c|c|c|}
\hline \multicolumn{2}{|c|}{ Synchronous generator } & \multicolumn{2}{c|}{ Brushless exciter } \\
\hline Type & GFY45648-4 H 3 & Type & GJG219TA \\
\hline Output & 1251 KVA PF 0.8 & Output & $18 \mathrm{KW}$ \\
\hline Volt & 400V 50HZ & DC & $95 \mathrm{~V}$ \\
\hline Curr & $1804 \mathrm{~A} 1500 \mathrm{RPM}$ & DC & $189 \mathrm{~A}$ \\
\hline Ex Volt & 95V, 4 POLES & Ex Volt & $70 \mathrm{~V}$ \\
\hline Ex Curr & $183 \mathrm{~V} \mathrm{IP} \mathrm{22S}$ & Ex Curr & $8.5 \mathrm{~A}$ \\
\hline Serial. No. & 82128145051 & Insul & $\mathrm{F}$ \\
\hline
\end{tabular}

\section{PROPOSED SYSTEM DESCRIPTION AND MODEL}

To investigate the voltage-current characteristics of the wound rotor induction motor in the generator operation mode, Matlab simulations (Table II) were performed under different load types including resistive, inductive and capacitive loads [3-5]. To supply the excitation DC current, a two phase rotor circuit of the slip ring motor can be connected $[6,7]$. As shown from the model in Figure 2 and Figure 4(c), the rotor circuit includes just two phases. This scheme of connection induced more magnetomotive force than the three phase connection $[8$, 9].

Corresponding author: Ayman Y. Al-Rawashdeh 
TABLE II. BLOCK DESCRIPTION OF THE MATLAB SIMULATION

\begin{tabular}{|c|c|}
\hline Block Name & Block description \\
\hline Simple gear & $\begin{array}{l}\text { Represents a fixed-ratio gear or gear box. No inertia } \\
\text { or compliance is modeled in this block. Connections } \\
\mathrm{B} \text { (base) and F (follower) are mechanical rotational } \\
\text { conserving ports. The relations between base and } \\
\text { follower rotation directions are specified with the } \\
\text { output shaft rotates parameter. }\end{array}$ \\
\hline Inertia & $\begin{array}{l}\text { The block represents an ideal mechanical rotational } \\
\text { inertia. It has one mechanical rotational conserving } \\
\text { port. The block positive direction is from its port to } \\
\text { the reference point. This means that the inertia torque } \\
\text { is positive if the inertia is accelerated in the positive } \\
\text { direction. }\end{array}$ \\
\hline $\begin{array}{l}\text { Ideal torque } \\
\text { source }\end{array}$ & $\begin{array}{l}\text { Represents an ideal source of torque that generates } \\
\text { torque at its terminals proportional to the input } \\
\text { physical signal. }\end{array}$ \\
\hline $\begin{array}{c}\text { Ideal } \\
\text { rotational } \\
\text { motion sensor }\end{array}$ & $\begin{array}{l}\text { Is a device that converts an across variable measured } \\
\text { between two mechanical rotational nodes into a } \\
\text { control signal proportional to the angular velocity or } \\
\text { angle. The sensor is ideal since it does not account } \\
\text { for inertia, friction, delays, energy consumption,etc. } \\
\text { Connections R and C are mechanical rotational } \\
\text { conserving ports and connections W and A are } \\
\text { physical signal output ports for velocity and angular } \\
\text { displacement, respectively. }\end{array}$ \\
\hline Torque sensor & $\begin{array}{l}\text { It is a device that converts a variable passing through } \\
\text { the sensor into a control signal proportional to the } \\
\text { torque with a specified coefficient of proportionality. } \\
\text { The sensor is ideal since it does not account for } \\
\text { inertia, friction, delays, energy consumption, etc. } \\
\text { Connections R and C are mechanical rotational } \\
\text { conserving ports that connect the sensor to the line } \\
\text { whose torque is being monitored. Connection } \mathrm{T} \text { is a } \\
\text { physical signal port that outputs the measurement } \\
\text { result. The sensor positive direction is from port R to } \\
\text { port C. }\end{array}$ \\
\hline $\begin{array}{c}\text { DC voltage } \\
\text { source }\end{array}$ & Ideal DC voltage source. \\
\hline DC machine & $\begin{array}{l}\text { Implements a (wound-field or permanent magnet) DC } \\
\text { machine. For the wound-field DC machine, access is } \\
\text { provided to the field connections so that the machine } \\
\text { can be used as a separately excited, shunt-connected } \\
\text { or a series-connected DC machine. }\end{array}$ \\
\hline $\begin{array}{l}\text { Asynchronous } \\
\text { machine }\end{array}$ & $\begin{array}{l}\text { Implements a three-phase asynchronous machine } \\
\text { (wound rotor, squirrel cage or double squirrel cage) } \\
\text { modeled in a selectable dq reference frame (rotor, } \\
\text { stator, or synchronous). Stator and rotor windings are } \\
\text { connected in wye to an internal neutral point. }\end{array}$ \\
\hline
\end{tabular}

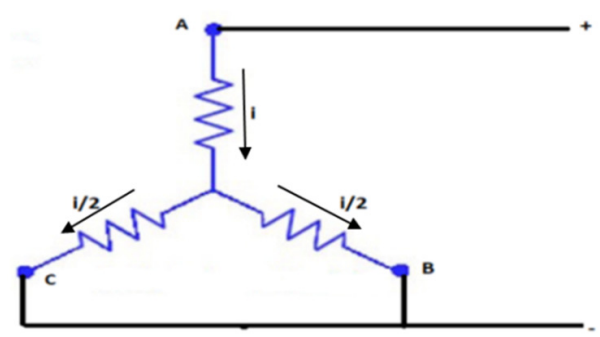

Fig. 2. The rotor circuit of the slip ring motor with two phases.

The total magnetomotive force of this connection for each harmonics can be calculated from:

$$
\mathrm{F}_{\mathrm{i}}=2 \mathrm{~F}_{\emptyset \mathrm{i}} \cos ^{2} \frac{\mathrm{i} \pi}{6}
$$

The relation between the first harmonic magnetomotive force of this connection to the first magneto motive force of the one phase is:

$$
\frac{\mathrm{F}}{\mathrm{F}_{\phi}}=\frac{2 \mathrm{~F}_{\varnothing} \cos ^{2} \frac{\pi}{6}}{\mathrm{~F}_{\varnothing}} \cong 1.5
$$

where $\mathrm{F}_{\mathrm{i}}, \mathrm{F}_{\varphi \mathrm{i}}$ are the total magnetomotive force and magnetomotive force of the one phase, respectively.

It could be clearly concluded that when the DC current is supplied by two phases of the rotor circuit, the total induced magnetomotive force is 1.5 times more than the induced magnetomotive force of one phase. The flowing DC excitation current by the rotor circuit (Figure 2), is used to induce the total machine's magnetomotive force in all three rotor phases $[10$, 11], and:

$$
\mathrm{I}=-\left(\mathrm{I}_{\mathrm{B}}-\mathrm{I}_{\mathrm{C}}\right)
$$

where $\mathrm{I}_{\mathrm{B}}=\mathrm{I}_{\mathrm{C}}=0.5 \mathrm{I}_{\mathrm{A}}$.

The suggested connection method of the rotor circuit shown in Figure 2, gives 1.15 times more magnetomotive force than the traditional connection in which the DC excitation current supplied by each phase separately. As a prime mover for the system a DC motor was used, coupled with a wound rotor motor by a gear box with 1:1 ratio (Figure 3(a)).

(a)

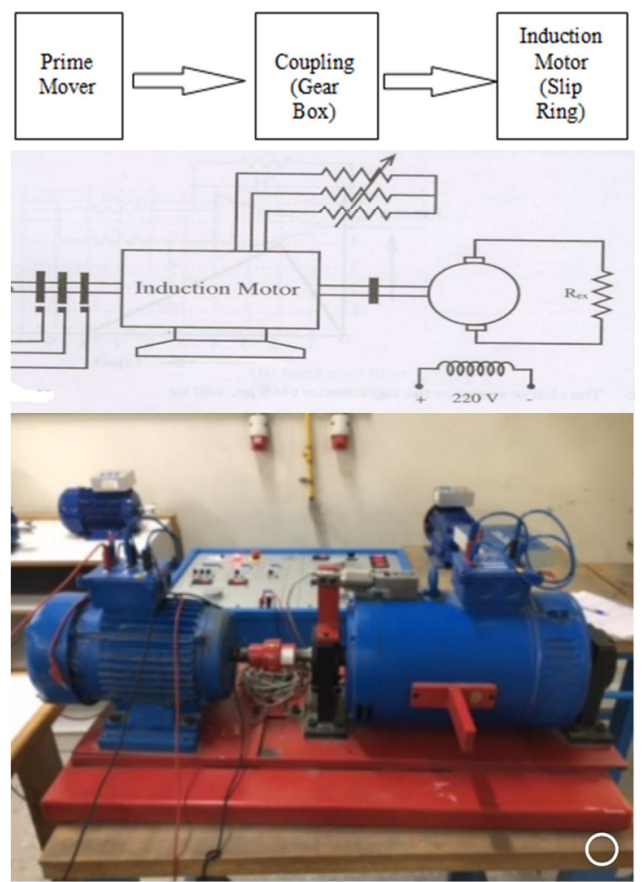

Fig. 3. (a) General model blocks of the system, (b) General model of the system, (c) The general model used to collect data .

Figure 3(b) shows the prime mover, DC motor and a wound rotor induction motor which is driven by the prime mover and is used to generate AC power. The excitation current of the induction motor is a DC current and it is supplied from an external DC source through a slip ring and carbon brushes [11]. Firstly, the prime mover is run to a rated speed and then, step 
by step, it supplies DC excitation current to wound rotor motor to record the measurements at no load and load operation conditions. The investigation process was done at a constant speed (speed of the prime mover), power factor and excitation current. At first, the experiment was done without load, to investigate the no load operation condition $\mathrm{E}_{\mathrm{a}}=\mathrm{f}\left(\mathrm{I}_{\mathrm{f}}\right)$ at $\mathrm{I}_{\mathrm{a}}=0$ and constant speed. Then the experiment was repeated with the same connection circuit but with different connecting loads, resistive, inductive and capacitive, to the terminals of the generator $[8,12,13]$. The output voltages and load currents were recorded using measurement devices. The rated parameters of the investigated motor were $\mathrm{V}_{\mathrm{S}}=220 \mathrm{~V}, \mathrm{P}=60 \mathrm{~W}$, $\mathrm{P}=1500 \mathrm{rpm}, \mathrm{I}_{\mathrm{f}}=1,7 \mathrm{~A}, \mathrm{I}_{\mathrm{st}}=0.47 \mathrm{~A}$.

\section{RESULTS AND DISCUSSION}

Firstly, the experiment was done without load to investigate the no load operation condition $\mathrm{E}_{\mathrm{a}}=\mathrm{f}\left(\mathrm{I}_{\mathrm{f}}\right)$ at $\mathrm{I}_{\mathrm{a}}=0$ and constant speed. Table III lists the experimental outputs of the module measured without load. Tables IV, V and VI, list the experimental outputs of the module as a function of the R-, Land C-loads, respectively.

TABLE III. EXPERIMENTAL OUTPUTS OF THE MODULE MEASURED AT NO-LOAD CONDITION.

\begin{tabular}{|c|c|}
\hline $\mathbf{I}_{\mathbf{f}}$ & $\mathbf{E}_{\mathbf{a}}$ \\
\hline 0 & 0 \\
\hline 0.2108 & 31.46 \\
\hline 0.2499 & 37.40 \\
\hline 0.3000 & 44.44 \\
\hline 0.4989 & 75.68 \\
\hline 0.6001 & 89.98 \\
\hline 0.9996 & 148.06 \\
\hline 1.4990 & 205.04 \\
\hline
\end{tabular}

TABLE IV. EXPERIMENTAL OUTPUTS OF THE MODULE MEASURED AS A FUNCTION OF R-LOAD

\begin{tabular}{|c|c|c|}
\hline $\mathbf{I}$ & $\mathbf{V}$ & $\mathbf{P}$ \\
\hline 0.00 & 229.90 & 0.00 \\
\hline 0.0300 & 220.88 & 9.96 \\
\hline 0.0696 & 211.86 & 19.98 \\
\hline 0.9960 & 203.94 & 30.00 \\
\hline 0.1297 & 194.92 & 39.69 \\
\hline 0.1598 & 187.88 & 49.98 \\
\hline 0.1899 & 179.96 & 60.00 \\
\hline 0.2096 & 177.92 & 69.96 \\
\hline 0.2298 & 165.88 & 79.98 \\
\hline
\end{tabular}

TABLE V. EXPERIMENTAL OUTPUTS OF THE MODULE MEASURED AS A FUNCTION OF L-LOAD.

\begin{tabular}{|c|c|c|}
\hline $\mathbf{I}$ & $\mathbf{V}$ & $\mathbf{L}$ \\
\hline 0.0696 & 211.86 & 0.000 \\
\hline 0.9960 & 188.98 & 0.416 \\
\hline 0.1396 & 169.84 & 0.833 \\
\hline 0.1795 & 154.00 & 1.250 \\
\hline 0.2096 & 139.92 & 1.666 \\
\hline
\end{tabular}

The measurements of voltage, current and power were recorded using a voltmeter, an ampere meter and a wattmeter. Results for the voltage, current and power outputs with different load types (Tables III, IV, V, and VI) are plotted graphically in Figure (5). The obtained simulation results were in total agreement with the experimental results and findings in
$[1,3]$. The results of the $\mathrm{R}$ and L-loads revealed that the output voltage of the generator decreased slightly as load increases. The results reveal the increase in the current of the generator with increasing load (Figure 5). The obtained results showed that the voltage - current characteristics with different load types had drooping (resistive and inductive) or rising (capacitive) character which can be explained by the effect of the rotor magnetic field - armature field - on the main magnetic field, especially with an increase in the load.

(a)

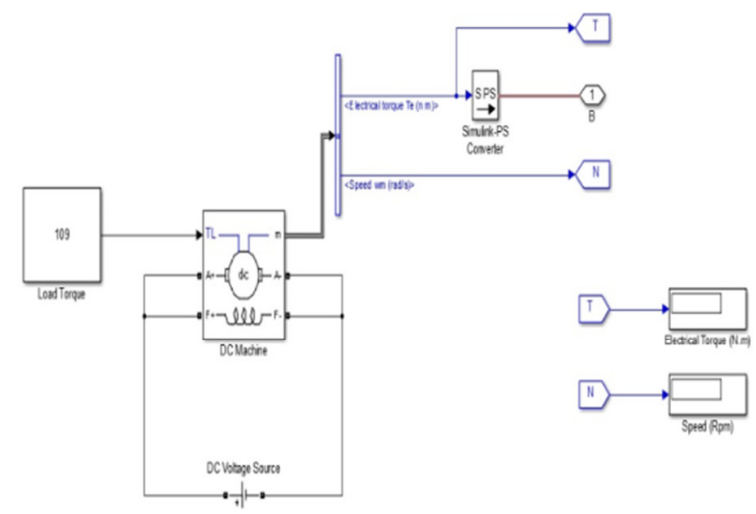

(b)
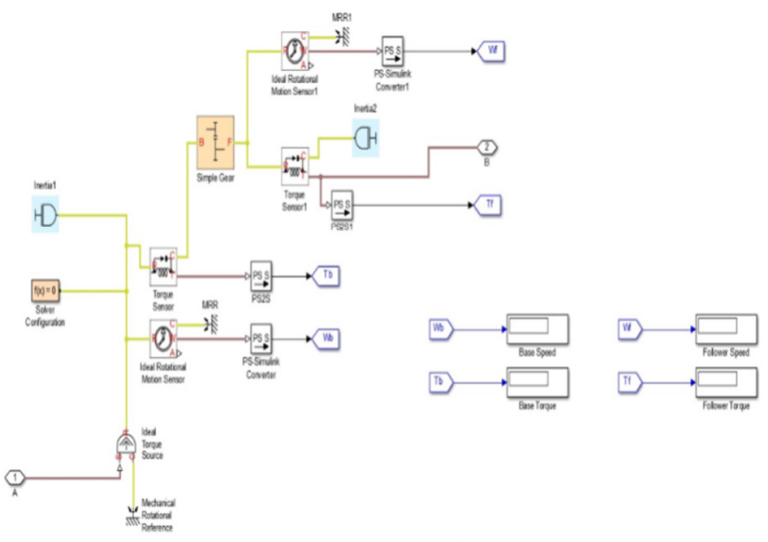

(c)

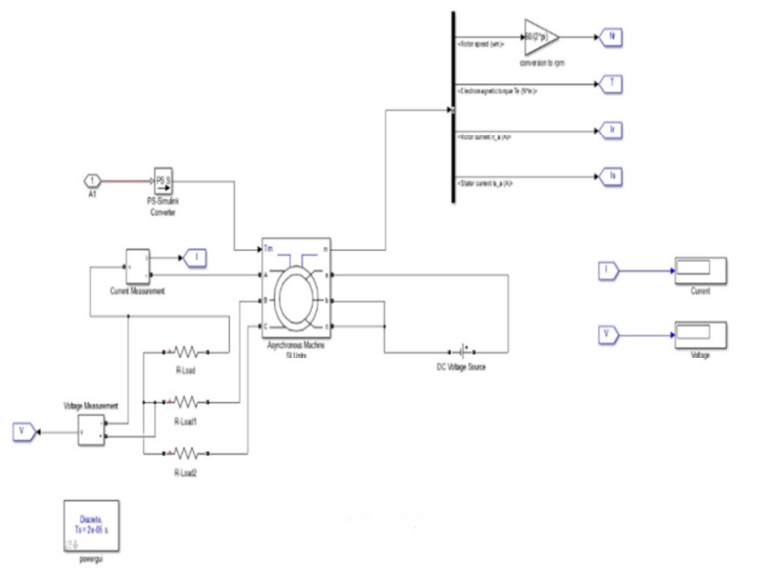

Fig. 4. (a) A simulation model of the prime mover, (b) A simulation model of the gear box, (c) A simulation model of the wound rotor 
TABLE VI. EXPERIMENTAL OUTPUTS OF THE MODULE MEASURED AS A FUNCTION OF C-LOAD.

\begin{tabular}{|c|c|c|}
\hline $\mathbf{I}$ & $\mathbf{V}$ & $\mathbf{C}$ \\
\hline 0.0696 & 211.86 & 0.000 \\
\hline 0.0696 & 216.92 & 0.416 \\
\hline 0.0898 & 224.84 & 0.833 \\
\hline 0.1099 & 231 & 1.250 \\
\hline 0.1297 & 236.94 & 1.666 \\
\hline
\end{tabular}

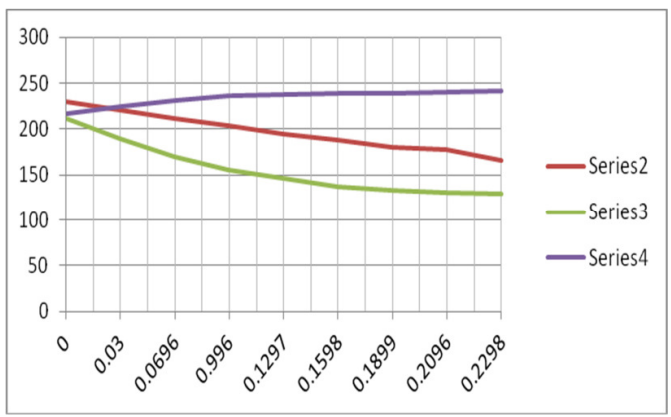

Fig. 5. Experimental relation between generated voltage and load current of a wound rotor induction motor with different load types.

\section{CONCLUSION}

The obtained results from the experiments conducted in the paper, revealed similarities between the wound rotor induction motor in generating operation mode, and the known characteristics of the synchronous generators. Based on the observed similarities, the current study provides a proof of the possible use of the wound rotor induction motor as an emergency power supply instead of the currently used old diesel generators.

\section{REFERENCES}

[1] K. Y. Patil, D. S. Chavan, "Use of Slip Ring Induction Generator for Wind Power Generation", International Journal of Engineering Research and Applications, Vol. 2, No. 4, pp.1107-1110, 2012

[2] S. Djurovic, D. S. Vilchis-Rodriguez, A. C. Smith, "Investigation of wound rotor induction machine vibration signal under stator electrical fault conditions", The Journal of Engineering, Vol. 2014, No. 5, pp. 248258,2014

[3] M. Barakat, S. Elmasry, M. E. Bahgat, A. A. Sayed, "Effect of Rotor Current Control for Wound Rotor Induction Generator on the Wind Turbine Performance", International Journal of Power Electronics and Drive System, Vol. 2, No. 2, pp. 117-126, 2012

[4] F. I. Bakhsh, M. M. Shees, M. S. J. Asghar, "Performance of Wound Rotor Induction Generators with the Combination of Input Voltage and Slip Power Control”, Russian Electrical Engineering, Vol. 85, No. 6, pp. 403-417, 2014

[5] O. Albarbarawi, A. Al-Rawashdeh, G. Qaryouti, "Simulink Modelling of the Transient Cases of Three Phase Induction Motors", International Journal of Electrical \& Computer Sciences, Vol. 17, No. 4, pp. 6-15, 2017

[6] D. Aguilar, G. Vazquez, A. Rolan, J. Rocabert, F. Corcoles, P. Rodriguez, "Simulation of Wound Rotor Synchronous Machine under Voltage Sags", 2010 IEEE International Symposium on Industrial Electronics, Bari, Italy, July 4-7, 2010

[7] E. Tuinman, P. Piers, R. de Weerdt, "Simulation of a direct on line start of a large induction motor connected to a salient pole synchronous generator", International Conference on Simulation '98, York, UK, September 30-October 2, 1998

[8] S. Devabhaktuni, S. V. Jayaram Kumar, "Different Self Excitation Techniques for Slip Ring Self Excited Induction Generator",
International Journal of Computer Applications, Vol. 38, No. 2, pp. 1926,2012

[9] C. H. Watanabe, A. N. Barreto, "Self-excited induction generator/forcecommutated rectifier system operating as a dc power supply", IEE Proceedings B - Electric Power Applications, Vol. 134, No. 5, pp. 225 260, 1987

[10] S. S. Murthy, O. P. Malik, A. K. Tandon, "Analysis of self-excited induction generators", IEE Proceedings C - Generation, Transmission and Distribution, Vol. 129, No. 6, pp. 260-265, 1982

[11] S. Devabhaktuni, S. V. Jayaram Kumar, "Selection of Capacitors for the Self Excited Slip ring Induction Generator with External Rotor Capacitance", Journal of Energy Technologies and Policy, Vol. 2, No. 2, pp. 66-77, 2012

[12] B. S. Srikanth, R. Anguraja, P. R. Khatei, "Experimental Investigation on an Induction Motor to Work as an Alternator", International Journal Of Scientific \& Engineering Research, Vol. 4, No. 5, pp. 129-132, 2013

[13] D. Aguilar, A. Luna, A. Rolan, G. Vazquez, G. Acevedo, "Modeling and Simulation of Synchronous Machine and its behavior against Voltage Sags", IEEE International Symposium on Industrial Electronics, Seoul, Korea, July 5-8, 2009

\section{AUTHORS PROFILE}

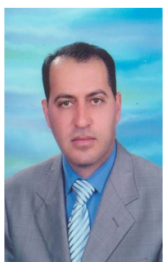

Dr. Ayman Y. Al-Rawashdeh PhD. Mechatronics. Eng, was born on 1970 in Jordan. He obtained his diploma degree in 1995 and $\mathrm{PhD}$ in 2008 in the field of Mechatronics Engineering. Currently he works as an Assistant Professor at the Electrical Department, Faculty of Engineering Technology, Al-Balqa Applied University, Jordan. His main interest is renewable energy and drive system analysis and simulations 